\title{
Electron and light microscopical observations and serological findings in rheumatoid arthritis
}

\author{
A. W. HELDER,* T. M. FELTKAMP-VROOM,* AND R. L. F. NIENHUIS $\dagger$ \\ From the *Central Laboratory of the Netherlands Red Cross Blood Transfusion Service and the Laboratory of \\ Experimental and Clinical Immunology, University of Amsterdam, and The $\uparrow$ Rheumatism Unit, Department of \\ Internal Medicine, State University Hospital, Groningen, The Netherlands
}

Various authors have discussed the serological, histopathological, and immunopathological disorders occurring in rheumatoid arthritis (Fassbender, 1971; Feltkamp, 1966, 1971; Glynn, 1972; Lindner, 1971; Müller, 1971), and reports on the submicroscopical structure of the normal synovial membrane (Barland, Novikoff, and Hamerman, 1962) and of the synovial tissue in rheumatoid arthritis (Bhan and Roy, 1971; Marin, Negoescu, Stoia, Pierrette, Petrescu, and Constantinescu, 1969; Norton and Ziff, 1966) have been published. From this work suggestions arose concerning a possible aetiological agent in rheumatoid arthritis. It has been demonstrated that aggregates of tubular structures (TS), morphologically resembling uncapsulated nucleocapsids of paramyxoviruses may be present in the cytoplasm of endothelial cells of blood vessels occurring in rheumatoid synovial tissue (Györkey, Min, and Györkey, 1969a). The presence of nuclear bodies and virus-like particles in the cells of the rheumatoid synovial membrane (Neumark and Farkas, 1970; Neumark, Hollos, and Farkas, 1971) is also suggestive of a virus involvement. The possible role of bacterial (Svartz, 1972) or mycoplasma infection (Jansson, Mäkisara, Vainio, Snellman, and Tuuri, 1971a; Jansson, Mäkisara, Vainio, Vainio, Snellman, and Tuuri, 1971b; Williams, Brostoff, and Roitt, 1970) in the development of rheumatoid arthritis has also been suggested. The purpose of this paper is to present the electron and light microscopical observations in tissues of patients with rheumatoid arthritis as well as the serological findings and to discuss our data in comparison with those described by other investigators.

\section{Material and methods}

Synovial membrane was obtained during operation from the finger or wrist joints of 25 patients with definite rheumatoid arthritis (Kellgren, 1962) (Table I), and from five patients with traumatic joint lesions of the knee, and from eight patients with degenerative joint lesions of the hip (Table II). Samples of reaction tissues developed round implanted silastic material in three patients were also examined (Table II). The group of 25 patients suffering from rheumatoid arthritis consisted of seven males and eighteen females, whose ages varied from 16 to 70 years. The control group of sixteen patients consisted of three males and thirteen females whose ages ranged from 3 to 80 years. After the operation the tissues were immediately fixed in a solution of glutaraldehyde and paraformaldehyde in $0 \cdot 1 \mathrm{M}$ phosphate buffer $\mathrm{pH} 7 \cdot 4$ (Karnovsky, 1965) for a period varying from 1 hour to several days. After having been rinsed for 1 hour in $0.1 \mathrm{M}$ phosphate buffer pH $7 \cdot 4$, the material was either dehydrated by increasing concentrations of ethanol and embedded in paraplast for the light microscopy or post-fixed in an ice-cold solution of 1 per cent. osmium tetroxide in phosphate buffer at pH 7.5 (Millonig, 1961) for electron microscopy. After post-fixation the tissue blocks were dehydrated as described above and subsequently embedded in Epon.

Paraplast sections of $4 \mu$ were stained with periodic acid-Schiff (PAS) and with phosphotungstic acid haematoxylin (PTAH). These sections were investigated according to the six criteria of Lindner (1971).

For electron microscopy, ultrathin sections $(40-50 \mathrm{~nm})$ of two tissue blocks from each specimen were cut with glass knives on a Reichert ultra-microtome, and stained with uranyl acetate for $20 \mathrm{~min}$. and then with lead hydroxide for $10 \mathrm{~min}$.

The tissue blocks from one patient with rheumatoid arthritis were fixed, embedded, and stained according to the method of Bernhard (1969).

The blocks were fixed for $30 \mathrm{~min}$. in 2 per cent. glutaraldehyde in $0.1 \mathrm{M}$ phosphate buffer $\mathrm{pH} \mathrm{7.4}$ and embedded in water-soluble glycolmethacrylate; the ultrathin sections were stained in: 0.5 per cent. aqueous uranyl acetate 30 $\mathrm{sec}$. to $1 \mathrm{~min}$., $0 \cdot 20 \mathrm{M}$ EDTA in distilled water 1 to $2 \mathrm{~min}$. lead hydroxide $10 \mathrm{sec}$. to $1 \mathrm{~min}$.

The electron microscopical investigation was performed with a Philips EM 300 electron microscope.

Serological tests for the presence of antinuclear antibodies (ANA) were carried out. If the result was negative, the serum dissociation technique of Blomjous and 
Table I Patients suffering from rheumatoid arthritis

\begin{tabular}{|c|c|c|c|c|c|c|c|c|c|c|c|c|c|c|c|c|}
\hline \multirow[t]{3}{*}{$\begin{array}{l}\text { Patient } \\
\text { no. }\end{array}$} & \multirow[t]{3}{*}{ Sex } & \multirow[t]{3}{*}{$\begin{array}{l}\text { Age } \\
(y r s)\end{array}$} & \multicolumn{5}{|c|}{ Serology } & \multicolumn{6}{|c|}{ Light microscopy } & \multicolumn{2}{|c|}{$\begin{array}{l}\text { Electron } \\
\text { microscopy }\end{array}$} & \multirow{3}{*}{$\begin{array}{l}\text { Duration } \\
\text { of disease } \\
(y r s)\end{array}$} \\
\hline & & & \multicolumn{2}{|l|}{$A N A$} & \multirow[t]{2}{*}{$R T$} & \multirow[t]{2}{*}{$L F T$} & \multirow[t]{2}{*}{$A P F$} & \multirow[t]{2}{*}{$a$} & \multirow[t]{2}{*}{$b$} & \multirow[t]{2}{*}{$c$} & \multirow[t]{2}{*}{$d$} & \multirow[t]{2}{*}{$e$} & \multirow[t]{2}{*}{$f$} & \multirow{2}{*}{$\begin{array}{l}\text { Comma- } \\
\text { shaped }\end{array}$} & \multirow[t]{2}{*}{ Tubular } & \\
\hline & & & Free & Hidden & & & & & & & & & & & & \\
\hline 1 & $\mathbf{F}$ & 41 & - & \pm & - & - & - & + & + & + & + & + & + & + & - & 3 \\
\hline 2 & $\mathbf{M}$ & 48 & - & + & - & - & + & + & + & + & + & + & + & + & - & 4 \\
\hline 3 & $\mathrm{~F}$ & 34 & + & & + & + & - & + & + & + & + & + & + & + & - & 11 \\
\hline 4 & $\mathrm{~F}$ & 59 & - & + & + & + & ++ & + & + & + & + & + & + & + & - & 3 \\
\hline 5 & $F$ & 59 & - & + & + & + & + & + & + & + & + & + & + & + & - & 10 \\
\hline 6 & $\mathrm{~F}$ & 21 & - & \pm & - & - & - & + & + & + & + & + & + & + & - & 2 \\
\hline 7 & $F$ & 47 & - & + & + & + & - & + & + & + & + & + & - & + & - & 20 \\
\hline 8 & $F$ & 63 & + & r & - & - & - & + & + & + & + & + & - & + & - & 15 \\
\hline 9 & $\mathbf{F}$ & 57 & - & + & + & + & + & + & + & + & \pm & + & - & + & - & 19 \\
\hline 10 & $F$ & 67 & - & \pm & + & + & - & + & + & + & \pm & + & + & + & - & 23 \\
\hline 11 & $F$ & 63 & - & + & - & - & - & + & + & + & - & + & - & + & - & 9 \\
\hline 12 & $\mathbf{M}$ & 55 & + & & + & + & ++ & + & + & + & - & + & - & - & - & 17 \\
\hline 13 & $\mathbf{F}$ & 47 & - & + & - & - & - & + & + & + & - & + & - & + & - & 8 \\
\hline 14 & $\mathbf{F}$ & 63 & - & - & + & + & - & + & + & + & - & + & - & + & - & 8 \\
\hline 15 & $\mathbf{F}$ & 57 & - & - & - & - & + & + & + & + & - & + & - & + & - & \\
\hline 16 & $\mathbf{M}$ & 70 & - & + & + & + & +++ & + & + & + & - & \pm & - & + & - & 6 \\
\hline 17 & $\mathbf{M}$ & 36 & - & - & + & + & + & + & + & + & - & \pm & - & + & - & 16 \\
\hline 18 & $\mathbf{F}$ & 70 & - & - & - & - & - & + & \pm & + & - & + & - & + & - & 2 \\
\hline 19 & $\mathbf{F}$ & 43 & - & + & - & - & + & + & \pm & + & - & \pm & - & + & - & 7 \\
\hline 20 & $\mathrm{~F}$ & 32 & - & \pm & - & + & +++ & + & \pm & + & - & \pm & - & + & - & 5 \\
\hline 21 & $\mathbf{M}$ & 43 & - & 亡 & - & - & ++ & \pm & \pm & \pm & - & + & - & + & - & 3 \\
\hline 22 & $\mathbf{M}$ & 16 & - & \pm & - & - & - & + & + & + & - & - & - & + & - & 2 \\
\hline 23 & $\mathbf{F}$ & 51 & ++ & & + & + & +++ & + & + & + & - & - & - & + & - & 21 \\
\hline 24 & $\mathbf{M}$ & 53 & - & + & - & + & - & + & + & + & + & - & - & + & - & 2 \\
\hline 25 & $\mathbf{F}$ & 65 & - & \pm & - & - & +++ & - & - & + & + & - & - & - & + & 19 \\
\hline$\overline{25}$ & & & 4 & $\overline{10}$ & 11 & $\overline{13}$ & 13 & 24 & 24 & 25 & 11 & 21 & 7 & 23 & 1 & \\
\hline
\end{tabular}

Table II Patients suffering from other diseases

\begin{tabular}{|c|c|c|c|c|c|c|c|c|c|c|c|c|c|c|c|c|}
\hline \multirow[t]{3}{*}{$\begin{array}{l}\text { Patient } \\
\text { no. }\end{array}$} & \multirow[t]{3}{*}{ Sex } & \multirow[t]{3}{*}{$\begin{array}{l}\text { Age } \\
\text { (yrs) }\end{array}$} & \multicolumn{5}{|c|}{ Serology } & \multicolumn{6}{|c|}{ Light microscopy } & \multicolumn{2}{|c|}{$\begin{array}{l}\text { Electron } \\
\text { microscopy }\end{array}$} & \multirow[t]{3}{*}{$\begin{array}{l}\text { Diag- } \\
\text { nosis }\end{array}$} \\
\hline & & & \multicolumn{2}{|c|}{$A N A$} & \multirow[t]{2}{*}{$R T$} & \multirow[t]{2}{*}{$L F T$} & \multirow[t]{2}{*}{$A P F$} & \multirow[t]{2}{*}{$a$} & \multirow[t]{2}{*}{$b$} & \multirow[t]{2}{*}{$c$} & \multirow[t]{2}{*}{$d$} & \multirow[t]{2}{*}{$e$} & \multirow[t]{2}{*}{$f$} & \multirow{2}{*}{$\begin{array}{l}\text { Comma- } \\
\text { shaped }\end{array}$} & \multirow[t]{2}{*}{ Tubular } & \\
\hline & & & Free & Hidden & & & & & & & & & & & & \\
\hline 1 & F & 62 & - & - & $1: 128$ & $1: 640$ & - & - & - & - & - & - & - & - & - & T.J.L. \\
\hline 2 & $\mathbf{M}$ & 40 & - & - & - & - & - & \pm & - & - & - & - & - & - & - & T.J.L. \\
\hline 3 & $\mathbf{F}$ & 63 & - & - & - & - & \pm & \pm & - & - & - & - & - & - & - & T.J.L. \\
\hline 4 & $\mathbf{M}$ & 17 & - & - & - & - & \pm & $=$ & - & - & - & - & - & - & - & T.J.L. \\
\hline 5 & $\mathbf{M}$ & 20 & - & - & - & - & - & - & - & - & - & - & - & - & - & T.J.L. \\
\hline 6 & F & 3 & nd & nd & nd & nd & nd & - & - & + & - & - & - & + & - & I.S. \\
\hline 7 & $\mathbf{F}$ & 80 & - & - & - & - & - & - & - & - & - & - & - & + & - & I.S. \\
\hline 8 & $\mathbf{F}$ & 32 & - & - & - & - & - & - & - & - & - & - & - & + & - & I.S. \\
\hline 9 & F & 70 & - & - & - & - & - & - & - & - & - & - & - & - & - & D.J.L. \\
\hline 10 & $\mathbf{F}$ & 70 & - & - & - & - & - & - & - & - & - & - & - & - & - & D.J.L. \\
\hline 11 & $\mathbf{F}$ & 65 & - & - & - & - & - & - & - & - & - & - & - & - & - & D.J.L. \\
\hline 12 & $\mathbf{F}$ & 76 & - & - & - & - & - & - & - & \pm & - & - & - & - & - & D.J.L. \\
\hline 13 & $\mathbf{F}$ & 75 & - & - & - & - & - & \pm & - & \pm & - & - & - & - & - & D.J.L. \\
\hline 14 & F & 75 & - & - & - & - & - & $=$ & - & - & - & - & - & - & - & D.J.L. \\
\hline 15 & $\mathbf{F}$ & 68 & - & - & - & - & - & - & - & - & - & - & - & - & - & DJ.L \\
\hline 16 & $\mathbf{F}$ & 67 & - & - & - & - & - & - & - & - & - & - & - & - & - & D.J.L. \\
\hline
\end{tabular}


Feltkamp-Vroom (1971) was applied; immune complexes of ANA and their antigens can be dissociated by dialysing the serum against $0.02 \mathrm{M}$ citrate buffer, $\mathrm{pH} 3 \cdot 2$, for $14 \mathrm{hrs}$ at $4^{\circ} \mathrm{C}$. The test for rheumatoid factors was performed by means of the Waaler-Rose test or the modified WaalerRose test (RT) (Feltkamp and van Rossum, 1968; van Loghem-Langereis, 1954) and the latex-fixation test (LFT) (Singer and Plotz, 1956). The serological test for the presence of antiperinuclear factors (APF) was done according to the method described by Nienhuis and Mandema (1964).

\section{Results}

The serological histopathological, and electron microscopical findings are summarized in Tables I and II.

\section{Serology}

In only four of the 25 patients suffering from rheumatoid arthritis were ANA detected before dissociation of the serum. After dissociation of the serum sixteen ANA negative sera became positive for the presence of hidden ANA. In the control group none of the patients showed ANA. If the RT and LFT were taken together, twelve of the 25 patients with rheumatoid arthritis showed negative results. When the APF was also included, only seven patients showed negative results. The RT and LFT of one patient of the control group were $1: 128$ and 1:640 respectively and the test for APF in two other patients of this group was positive.

\section{Light microscopy}

The six criteria of Lindner (1971) are, in brief:

(a) Proliferation of the synovial membrane

(b) Proliferation of the synovial lining layer, occasionally with giant cells

(c) Infiltration of lymphocytes, plasma cells, and sometimes polymorphonuclear cells (d) Focal lymphocytic infiltration

(e) Deposits of fibrin and fibrinoid necrosis

$(f)$ Focal cellular necrosis.

Fig. 1 presents a light microscopical picture of a rheumatoid synovial membrane, showing some of these criteria. Criteria $(a)$ and $(b)$ were present in the synovial tissue of 24 patients and criterion $(c)$ in all 25 patients suffering from rheumatoid arthritis. One patient showed only an infiltration of mononuclear cells and lymphoid nodules in the synovial membrane. Three patients from the control group showed a minimal proliferation of the synovial membrane and three showed an infiltration of mononuclear cells.

\section{Electron microscopy}

The synovial lining layer consists of three cell types (Fig. 2).

The first type (A cell) is characterized by numerous lysosomal organelles, a well-developed Golgi apparatus, several mitochondria, and a few lamellae of the rough endoplasmic reticulum (Fig. 3). There is a large, polygonal nucleus, the nuclear chromatin being concentrated in a narrow rim along the nuclear membrane.

The second type (B cell) has a well-developed rough endoplasmic reticulum and Golgi apparatus, numerous mitochondria, few lysosomal organelles, and bundles of fibrillar material (Fig. 4). The nucleus has the same appearance as in the A cell.

The third type (intermediate) contains numerous lysosomal organelles and a well-developed rough endoplasmic reticulum (Fig. 5). In patients with rheumatoid arthritis this synovial lining layer shows a proliferation of such cells in contrast to the synovial lining layer of the control patients.

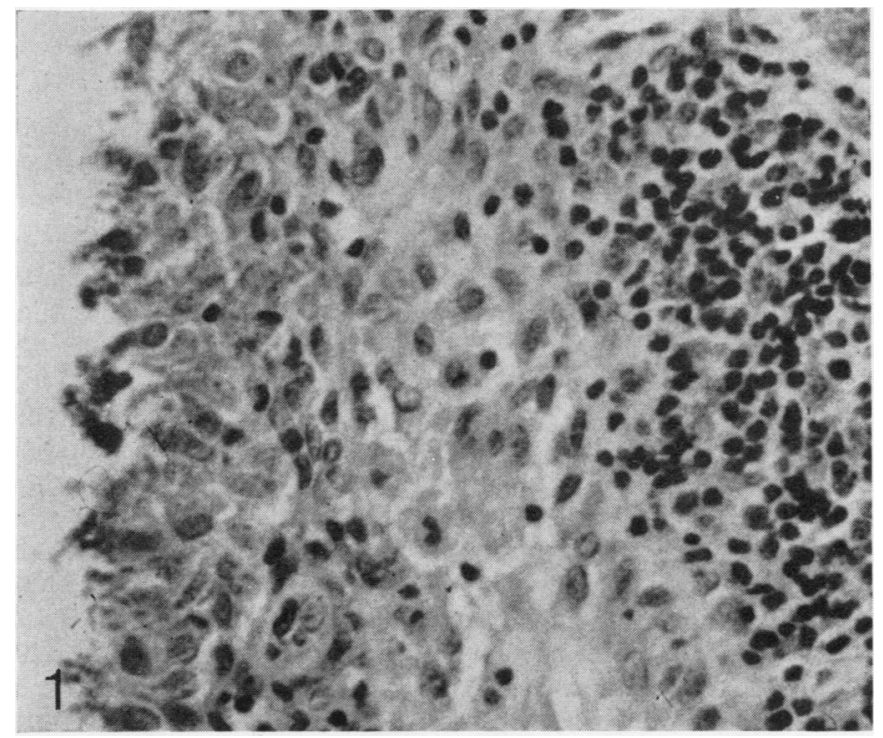

FIG. 1 Light microscopical picture of rheumatoid synovial membrane. Proliferation of synovial lining layer and mononuclear cell infiltration in deeper layer of synovial membrane are clear. $\times 500$ 
FIG. 3 Higher magnification of $A$ cell with several lysosomes (arrows), mitochondria (crossed arrows), Golgi apparatuses (triangles), and rough endoplasmic reticulum (asterisk). $\times 13,000$

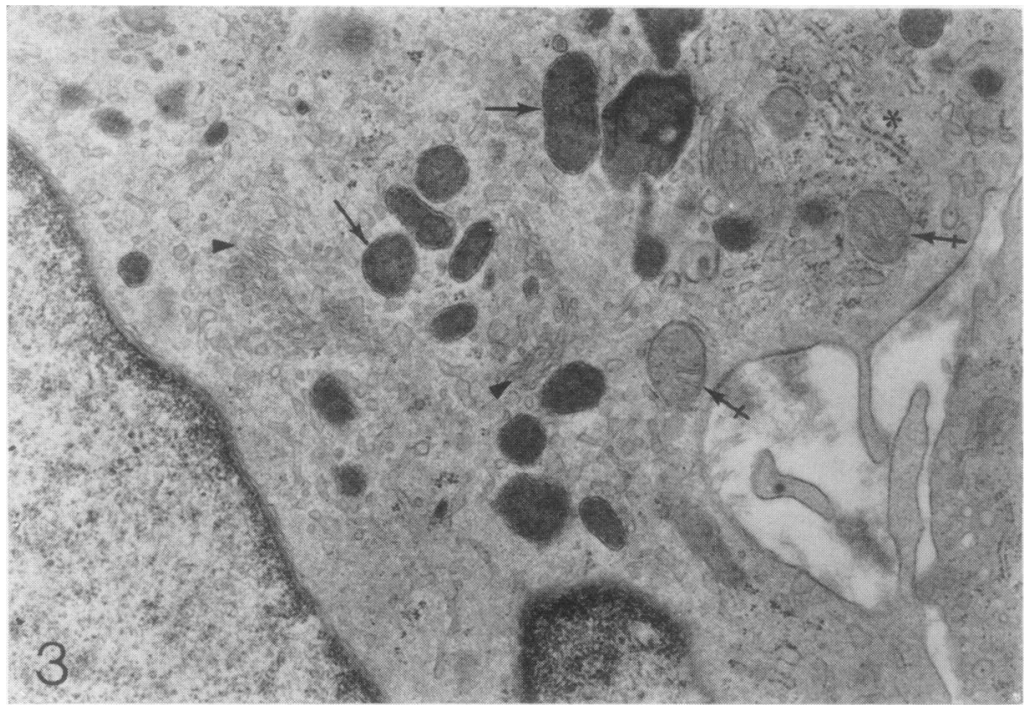

Fig. 6 shows some cell types in the deeper layer of the rheumatoid synovial membrane. One can easily distinguish a plasma cell with a characteristic, welldeveloped rough endoplasmic reticulum and many mitochondria, a cytoplasmic fragment of a macrophage with some lysosomal organelles, vacuoles, and several mitochondria, and finally a fragment of an elongated fibroblastic cell including a nucleus and numerous collagen fibres along the cell membrane. Mast cells are frequently seen in the deeper layer of the rheumatoid synovial membrane, having several granules with a characteristic shape in the cytoplasm (Fig. 7).

Fig. 8 shows part of a blood vessel; the endothelial cells often have a swollen appearance and the cyto-
FIG. 2 Part of rheumatoid synovial lining layer. Type A cell $(A)$ with several lysosomal organelles, type $B$ cell $(B)$ with a welldeveloped rough endoplasmic reticulum and intermediate cell (I) having both morphologic properties. $\times 3,200$ plasm contains many cell organelles and some bundles of filaments. The deeper layer of the rheumatoid synovial membrane shows a distinct increase in macrophages, plasma cells, and mast cells. In the synovial membrane of 23 patients suffering from rheumatoid arthritis, the cytoplasm of certain cells that bear a morphological resemblance to histiocytic cells shows aggregates of comma-shaped structures (CS). These cells have a more or less elongated form; the cytoplasm contains some rough endoplasmic reticulum, a few vacuoles, occasionally lysosomal organelles, and some mitochondria (Fig. 9). These cells belong to the deeper layer of the synovial membrane. The CS are slightly curved and seem to be confined by a double-layered membrane. The outer 


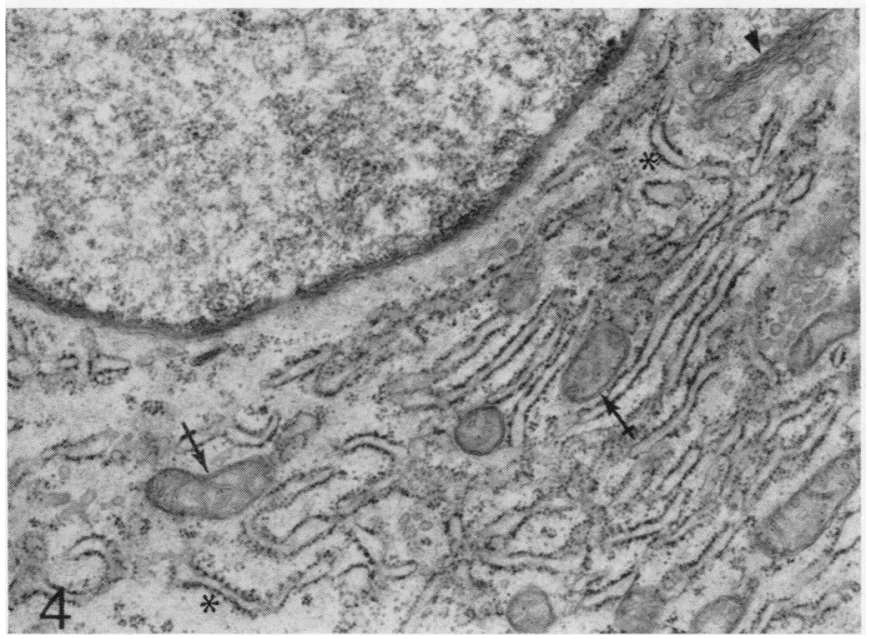

FIG. 4 Higher magnification of $B$ cell with well-developed rough endoplasmic reticulum (asterisk), Golgi apparatus (triangle), and mitochondria (crossed arrows). $\times 13,000$

FIG. 5 Higher magnification of intermediate cell with several lysosomal organelles (arrows), well-developed rough endoplasmic reticulum (asterisks), and many mitochondria (crossed arrows). $\times 10,500$
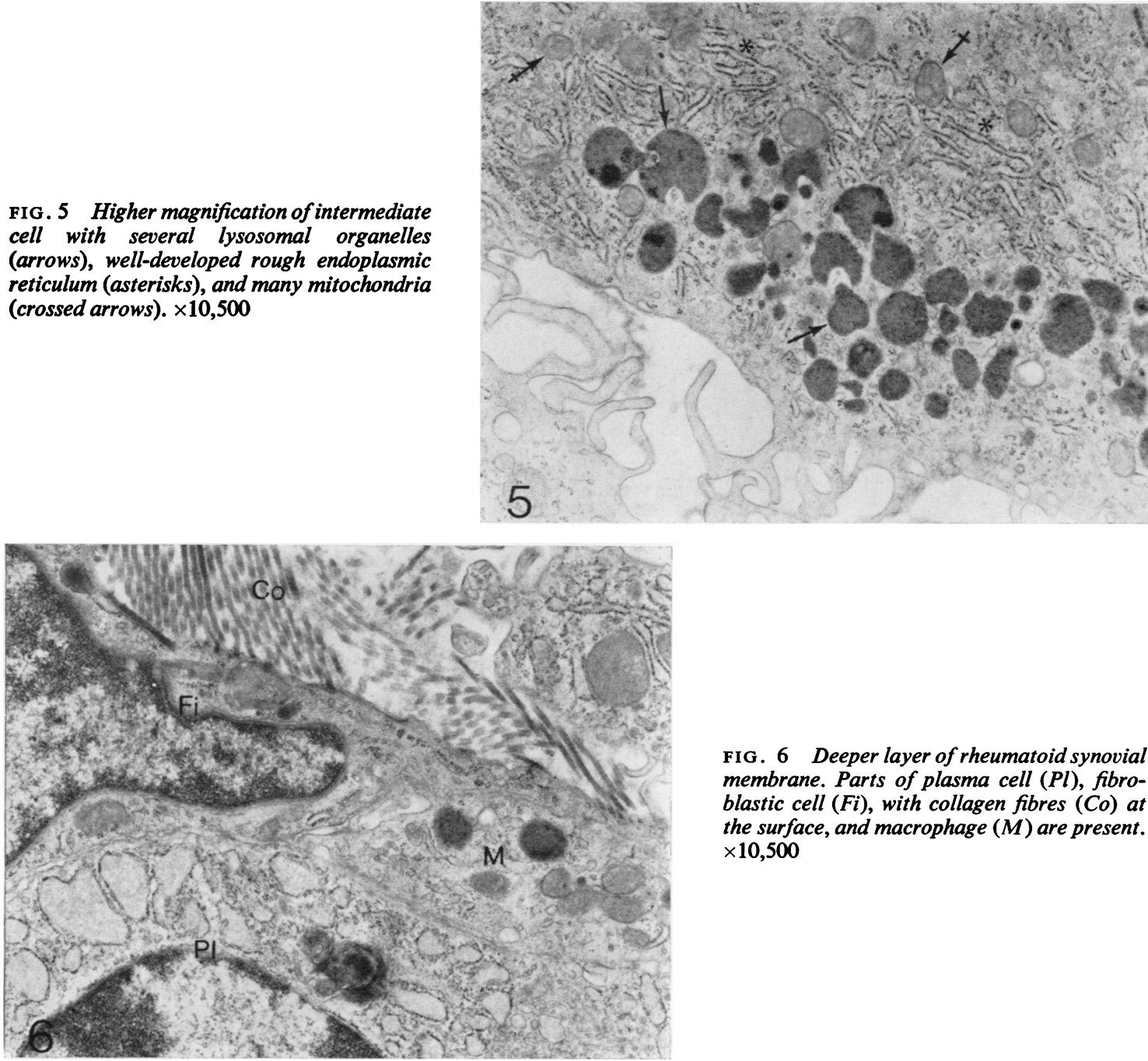

FIG. 6 Deeper layer of rheumatoid synovial membrane. Parts of plasma cell (Pl), fibroblastic cell (Fi), with collagen fibres (Co) at the surface, and macrophage $(M)$ are present. $\times 10,500$ 


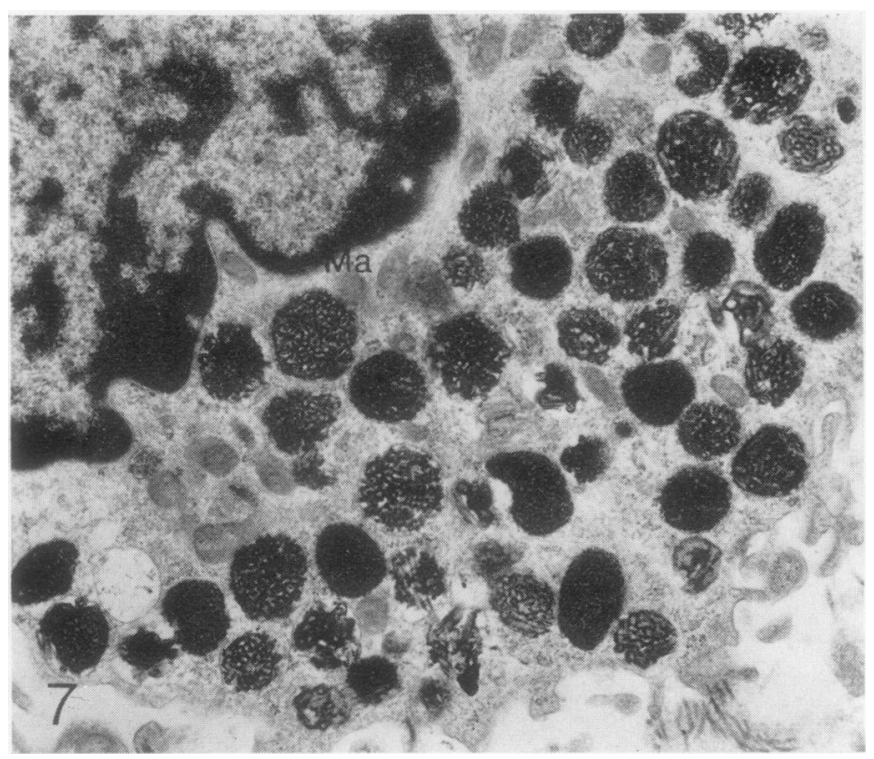

FIG. 7 Mast cell (Ma) with characteristic intracytoplasmic granules frequently noted in deeper layer of rheumatoid synovial membrane. $\times 10,500$

FIG. 8 Part of an endothelial cell of blood vessel in deeper layer of rheumatoid synovial membrane, showing swollen active appearance. Remarkable is the large nucleus and the abundance of cell organelles as the rough endoplasmic reticulum (asterisks), the Golgi apparatus (triangle), and the mitochondria (crossed arrows). $\times 10,500$

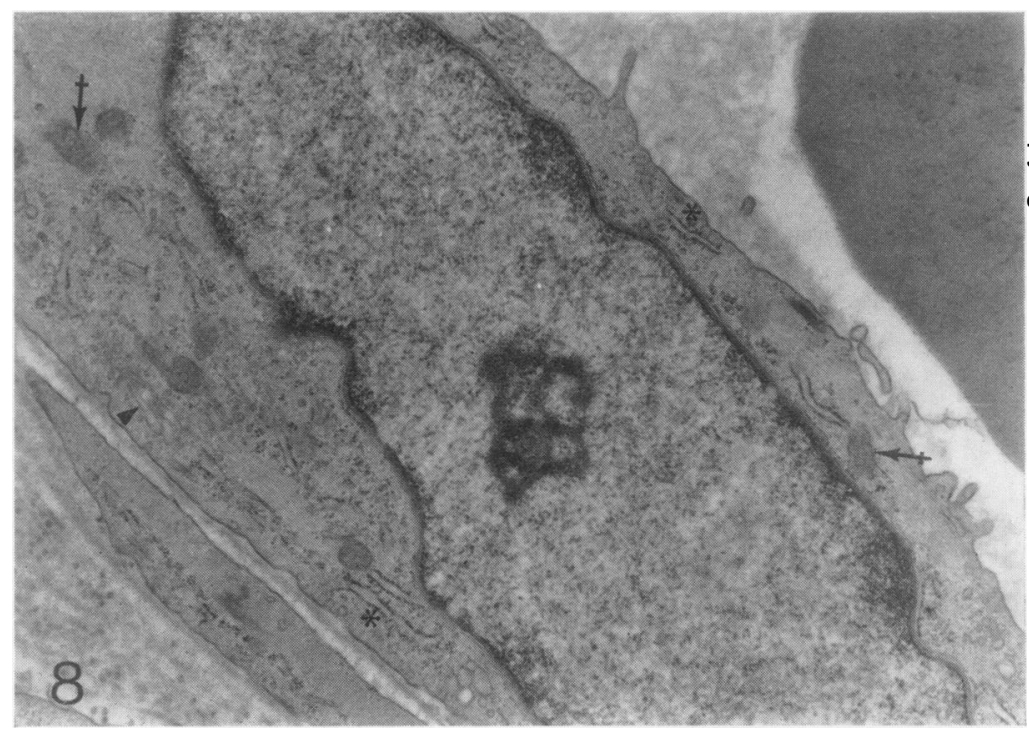

diameter amounts to about $24 \mathrm{~nm}$. and the inner diameter to about $12 \mathrm{~nm}$. The length varies from 100 to $300 \mathrm{~nm}$. The structures contain material with a more electron dense appearance than the surrounding cytoplasmic matrix (Fig. 10). A distinct connection between these structures and intracytoplasmic membranes has never been observed. The CS were never found in the other cell types of the rheumatoid synovial membrane.

CS were not observed in synovial tissue from patients with traumatic and degenerative joint lesions. They were, however, found to be present in cells of reaction tissue, developed after an implantation of silastic material. The staining method of Bernhard
(1969) did not give an indication for RNA in these CS. One patient suffering from rheumatoid arthritis showed the presence of aggregates of TS in the cytoplasm of endothelial cells of the blood vessels and of infiltrated lymphoid cells.

In the control group these aggregates of TS were never observed.

\section{Discussion}

In the group of 25 patients suffering from rheumatoid arthritis, sixteen ANA-negative sera revealed the so-called hidden ANA after dissociation, suggestive of the presence of circulating soluble immune 


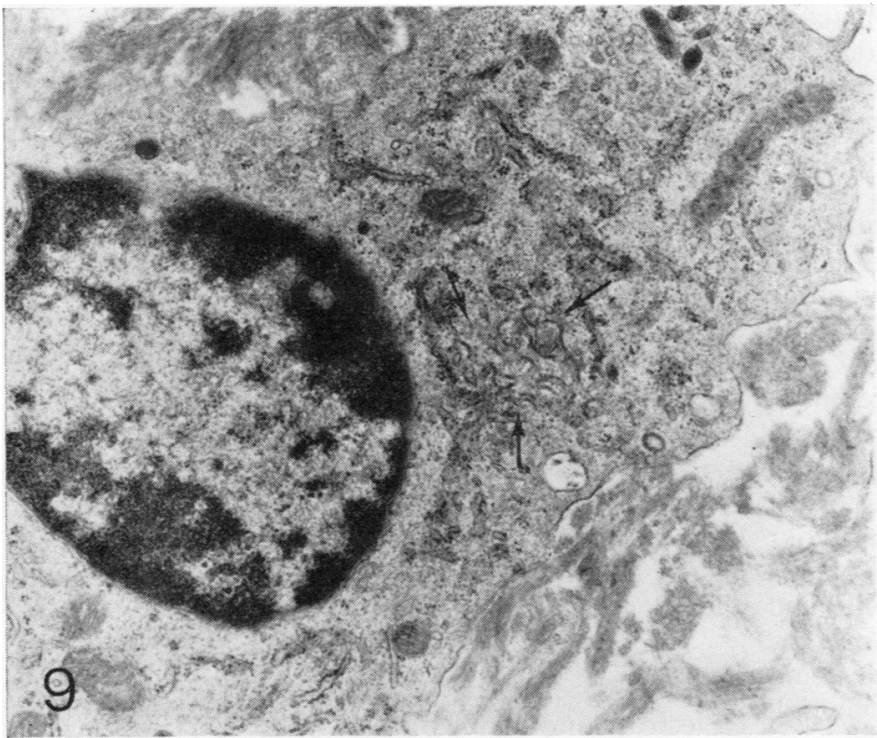

FIG. 9 Cell containing faintly curved structures free in cytoplasm (arrows). $\times 13,000$

FIG. 10 Higher magnification of part of same cell. A cross-section of these structures can occasionally be seen (arrow). $\times 66,000$

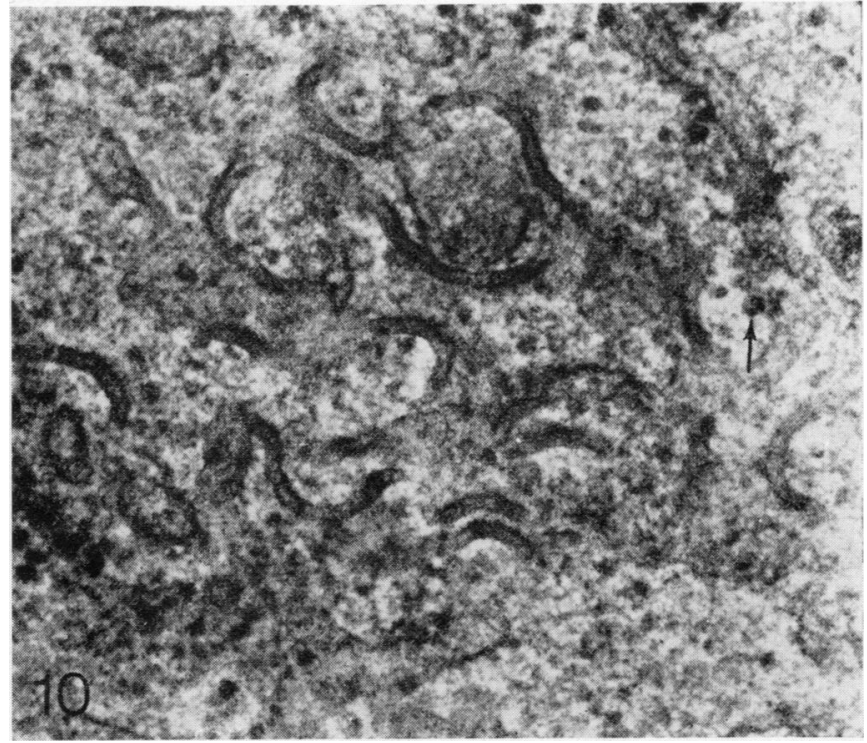

complexes, consisting of nuclear antigens and antibodies to nuclear antigens. The importance of the test for APF for the diagnosis of rheumatoid arthritis and for the differential diagnosis with regard to lupus erythematosus has been mentioned in the literature (Marmont, Damasio, Bertorello, and Rossi, 1967; Nienhuis and Mandema, 1964). In our group of 25 patients with definite rheumatoid arthritis, five patients with a negative RT and LFT had APF in the serum; we think therefore that the test for APF is valuable for the diagnosis of rheumatoid arthritis. In the group of seven patients with a negative RT, LFT, and APF test, the duration of disease was 2 to 15 years. We therefore have the impression that in our series no distinct correlation exists between the number of positive serological tests and the duration of rheumatoid disease. In the control group one patient had a positive RT and LFT and two patients a positive APF test. It is difficult to explain these phenomena, as specific clinical data for these patients were lacking.

Using the criteria proposed by Lindner (1971), the light microscopical investigation demonstrated that proliferation of synovial membrane, proliferation of lining layer, infiltration of lymphoid and plasma cells, and fibrin deposits and fibrinoid necrosis are present in almost all cases. Only an infiltration of mononuclear cells in the deeper layer of the synovial membrane 
was observed in one patient. The electron microscopy of the synovial tissue of this patient revealed the presence of TS in several endothelial and infiltrated lymphoid cells. However, the history and clinical data, as well as the distinct positive APF test, supported the diagnosis rheumatoid arthritis. The control group showed no light microscopical lesions indicative of rheumatoid arthritis.

An extensive submicroscopical investigation of the cells in the synovial membrane revealed that only the synovial tissue of the above mentioned patient with rheumatoid arthritis, contained TS in some endothelial cells and lymphoid cells. This confirms the findings described in an earlier report (Györkey and others, 1969a), and also indicates that the presence of TS in rheumatoid synovial tissue is rare. During our submicroscopical study we were not able to confirm the observations of Neumark and Farkas (1970) and Neumark and others (1971), who demonstrated the presence of nuclear bodies, virus-like particles, and nucleocapsid-like structures in rheumatoid material. The occurrence of CS in certain cells of the rheumatoid synovial membrane was striking; these cells have a morphological resemblance to histiocytic cells. The structures are slightly curved, are never found in the dilated cisternae of the endoplasmic reticulum, never show a distinct perinuclear localization, and do not occur in the cytoplasm of endothelial cells. We were not able to find any hint of the presence of RNA in these structures. We concluded that CS cannot be identified with the TS observed in patients with autoimmune and non-autoimmune diseases (Feltkamp-Vroom, and Helder, 1972; Györkey, Min, Sinkovics, and Györkey, 1969b; Helder, Blomjous, Feltkamp-Vroom, and van Loghem, 1971; Norton, Velayos, and Robison, 1970). The CS found in rheumatoid synovial tissue bear a very close morphological resemblance to the cytoplasmic membranous complex in histiocytosis X (Basset, Escaig, and Le Crom, 1972). They are confined by a membrane having the characteristics of the unit membrane. No distinct connection with the intracytoplasmic membranes was observed in this series; circular profiles were rare. It is therefore likely that we are dealing with flattened structures instead of tubular profiles. Similar structures have been described in tumours induced by Rous sarcoma virus (Smith and Deinhardt, 1968).

In some cells of reaction tissues, developed around implanted silastic material, identical structures could be observed, but CS were not present in the cells of the synovial tissue from patients with traumatic and degenerative joint lesions. This probably indicates a tissue reaction of other origin than in the case of rheumatoid arthritis and of silastic implantation.
The proliferation of fibroblastic and histiocytic cells is more prominent in rheumatoid arthritis and after implantation of silastic material; overloading of the phagocytosis in rheumatoid synovial tissue and the inability of silastic material to be phagocytosed can give rise to this increase of fibroblastic and histiocytic cells, possibly connected with the presence of CS. It is therefore likely that CS are not characteristic of one disease.

Finally, these rheumatoid tissues were used in our laboratory in an attempt to confirm the transfer experiments of Warren, Marmor, Liebes, and Hollins (1969), who succeeded in transmitting rheumatoid arthritis from men to mice. We were not able to transfer rheumatoid arthritis by injecting cell-free filtrates of rheumatoid tissues intraperitoneally into mice (Kruit, Feltkamp, de Blécourt, and Nienhuis, 1973).

\section{Summary}

Electron and light microscopical and serological observations are described in 25 patients with rheumatoid arthritis, in thirteen patients suffering from other joint lesions, and in three patients with silastic implants. Dissociation of the sera from rheumatoid patients revealed more sera with detectable antinuclear antibodies, compared with the routine antinuclear antibodies determination. The value of the test for antiperinuclear factors in the serum for the diagnosis of rheumatoid arthritis is stressed.

The light microscopy was performed using the six criteria of Lindner (1971). In certain cells with a histiocytic cell-like morphology, electron microscopy showed flattened comma-shaped structures. These cells were found not only in rheumatoid synovial tissue, but also in reaction tissue developed after the implantation of silastic material. So-called tubular structures were found in some endothelial cells of only one patient suffering from rheumatoid arthritis.

The nature and possible significance of the commashaped and tubular structures are unknown.

The authors wish to express their thanks to Drs. H. J. B. van Dijk (Weesperplein Ziekenhuis, Amsterdam), J. C. Tetzner (Dijsselhof kliniek, Amsterdam), and Th. J. G. van Rens (Onze Lieve Vrouwe Gasthuis, Amsterdam) for kindly supplying the tissues for their study.

They also wish to acknowledge the excellent technical assistance of Mrs. H. M. Rutgers-Roedema, Mr. J. Agterberg, Mrs. C. B. de Graaff-Reitsma, and Miss G. van Loo.

They are grateful to Miss D. Sjouwerman, Mr. P. Meelker, and Mr. A. Jans for the photographs and to Mrs. M. van Wijck-Scholten for typing the manuscript.

\section{References}

Barland, P., Novikoff, A. B., ANd Hamerman, D. (1962) J. Cell Biol., 14, 207 (Electron microscopy of the human synovial membrane) 
Basset, F., Escaig, J., ANd Le Crom, M. (1972) Cancer, 29, 1380 (A cytoplasmic membranous complex in histiocytosis $\mathrm{X}$ )

BernhARD, W. (1969) J. Ultrastruct. Res., 27, 250 ( A new staining procedure for electron microscopical cytology)

Bhan, A. K., AND Roy, S. (1971) Ann. rheum. Dis., 30, 294 (Synovial giant cells in rheumatoid arthritis and other joint diseases)

Blomjous, F. J. E. M., and Feltкamp-Vroom, T. M. (1971) Eur. J. Immunol., 1, 396 (Hidden anti-nuclear antibodies in sero-negative systemic lupus erythematosus patients and in NZB and (NZB $\times N Z W) F_{1}$ mice)

FASSBENDER, H. G. (1971) 'Histo-pathological changes in rheumatoid arthritis and their genesis from the point of view of the pathologist', in 'R heumatoid Arthritis', ed. W. Müller, H. G. Harwerth, and K. Fehr, pp. 7-24. Academic Press, London and New York

FeltKamp, T. E. W. (1966) 'Idiopathic autoimmune disease. A study of their serological relationship'. Thesis, Aemstelstad, Amsterdam

(1971) 'Antinuclear antibodies', in 'Rheumatoid Arthritis', ed. W. Müller, H. G. Harwerth, and K. Fehr, pp. 433435. Academic Press, London and New York

- AND Rossum, A. L. van (1968) Clin. exp. Immunol., 3, 1 (Antibodies to salivary duct cells, and other autoantibodies, in patients with Sjögren's syndrome and other idiopathic autoimmune diseases)

FeltKamp-Vroom, T. M., AND Helder, A. W. (1972) 'Tubular structures, antinuclear antibodies, and renal disease', in 'Proc. V International Congress of Nephrology, Mexico'.

GlynN, L. E. (1972) Ann. rheum. Dis., 31, 412 (Pathology, pathogenesis and aetiology of rheumatoid arthritis)

GyörKey, F., MIN, K. W., AND GYöRKEY, P. (1969a) Arthr. and Rheum., 12, 300 (Myxovirus-like structures in human collagen diseases)

—- —- Sinkovics, J. G., AND Györkey, P. (1969b) New Engl. J. Med., 280, 333 (Systemic lupus erythematosus and myxovirus)

Helder, A. W., Blomjous, F. J., Feltkamp-Vroom, T. M. and Loghem, J. J. van (1971) Lancet, 1, 1183 (Microtubules of systemic lupus erythematosus)

Jansson, E., Mäkisara, P., Vainio, K., Snellman, O., ANd TuUri, S. (1971a) Acta rheum. scand., 17, 227 (Further studies on mycoplasma in rheumatoid arthritis)

- - - - - Vainio, U., Snellman, O., ANd TuUri, S. (1971b) Ann. rheum. Dis., 30, 506 (An 8-year study on mycoplasma in rheumatoid arthritis)

KARNOvSKY, M. J. (1965) J. Cell Biol., 27, 137 (A formaldehyde-glutaraldehyde fixative of high osmolality for use in electron microscopy)

Kellgren, J. H. (1962) Bull. rheum. Dis., 13, 291 (Diagnostic criteria for population studies)

Kruit, W. F., Feltkamp, T. E. W., De BlÉcourt, J. J., ANd Nienhuis, R. L. F. (1973) Arch. intern. Med., 131, 304 (Transmissibility of rheumatoid arthritis from men to mice)

LINDNER, J. (1971) 'Self-perpetuation in rheumatoid arthritis from the morphological and biochemical points of view', in 'Rheumatoid Arthritis', ed. W. Müller, H. G. Harwerth, and K. Fehr, pp. 283-294. Academic Press, London and New York

Loghem-Langereis, P. E. van (1952) Bull. Centr. Lab. Bloedtransfusiedienst Ned. Rode Kruis, 2, 230 (Onderzoek van methoden naar de agglutinatie bevorderende factor in sera van patiënten met rheumatoide arthritis)

Marin, D., Negoescu, M., Stoia, I., Pierrette, A., Petrescu, A., and Constantinescu, S. (1969) Acta rheum. scand., 15, 126 (The morphology of the synovial tissue and articular fluid cellls in rheumatoid polyarthritisstudied with the optical and electronic microscope)

Marmont, A. M., Damasio, E. E., Bertorello, C., And Rossi, F. (1967) Arthr. and Rheum., 10, 117 (Studies on the antiperinuclear factor)

Millonig, G. (1961) J. appl. Physiol., 32, 1637 (Advantages of a phosphate buffer for OsO4 solutions in fixation)

MüLlER, W, (1971) Immunological reactivity in rheumatoid arthritis, in 'Rheumatoid Arthritis', ed. W. Müller, H. G. Harwerth, and K. Fehr, pp. 297-303. Academic Press, London and New York.

Neumark, T., and Farkas, K. (1970) Ann. rheum. Dis., 29, 653 (Nuclear bodies in rheumatoid synovium)

—, Hollos, I., AND FARKAS, K. (1971) Uni Lekarstoi, 17, 625 (Electron microscopical investigation of virus-like particles in rheumatoid synovial membrane)

Nienhuis, R. L. F., ANd Mandema, E. (1964) Ann. rheum. Dis., 23, 302 (A new serum factor in patients with rheumatoid arthritis. The antiperinuclear factor)

Norton, W. L., Velayos, E., AND Robison, L. (1970) Ibid., 29, 67 (Endothelial inclusions in dermatomyositis) , AND ZIFF, M. (1966) Arthr. and Rheum., 9, 589 (Electron microscopic observations on the rheumatoid synovial membrane)

Singer, J. M., ANd Plotz, C. M. (1956) Amer. J. Med., 21, 888 (The latex-fixation test)

Smith, R. D., AND Deinhardt, F. (1968) J. Cell Biol., 37, 819 (Unique cytoplasmic membranes in Rous sarcoma virus-induced tumors of a subhuman primate)

Svartz, N. (1972) Acta med. scand., 192, 231 (The primary cause of rheumatoid arthritis is an infection-the infectious agent exists in milk)

Warren, S. L., Marmor, L., Liebes, D. M., And Hollins, R. (1969) Arch. intern. Med., 124, 629 (An active agent from human rheumatoid arthritis which is transmissible in mice)

Williams, M. H., BRostoff, J., AND RoItT, I. M. (1970) Lancet, 2, 277 (Possible role of mycoplasma fermentans in pathogenesis of rheumatoid arthritis) 